\title{
Rapid Detection of Phytophthora infestans in Late Blight-Infected Potato and Tomato Using PCR
}

\author{
C. L. Trout, J. B. Ristaino, M. Madritch, and T. Wangsomboondee, Department of Plant Pathology, North Caro- \\ lina State University, Raleigh 27695
}

\begin{abstract}
Trout, C. L., Ristaino, J. B., Madritch, M., and Wangsomboondee, T. 1997. Rapid detection of Phytophthora infestans in late blight-infected potato and tomato using PCR. Plant Dis. 81:10421048.

Late blight caused by the oomycete pathogen Phytophthora infestans is a devastating disease of potato and tomato worldwide. A rapid and accurate method for specific detection of $P$. infestans is necessary for determination of late blight in infected fruit, leaves, and tubers. Ribosomal DNA (rDNA) from four isolates of $P$. infestans representing the four genotypes US1, US6, US7, and US8 was amplified using polymerase chain reaction (PCR) and the universal primers internal transcribed spacer (ITS) 4 and ITS5. PCR products were sequenced using an automated sequencer. Sequences were aligned with published sequences from 5 other Phytophthora species, and a region specific to $P$. infestans was used to construct a PCR primer (PINF). Over 140 isolates representing 14 species of Phytophthora and at least 13 other genera of fungi and bacteria were used to screen the PINF primer. PCR amplification with primers PINF and ITS5 results in amplification of an approximately 600 base pair product with only isolates of $P$. infestans from potato and tomato, as well as isolates of $P$. mirabilis and $P$. cactorum. P. mirabilis and $P$. cactorum are not pathogens of potato; however, P. cactorum is a pathogen of tomato. P. infestans and $P$. cactorum were differentiated by restriction digests of the amplified product. The PINF primer was used with a rapid $\mathrm{NaOH}$ lysis technique for direct PCR of $P$. infestans from infected tomato and potato field samples. The PINF primer will provide a valuable tool for detection of $P$. infestans in potatoes and tomatoes.
\end{abstract}

Additional keywords: disease diagnosis

Late blight, caused by the heterothallic, oomycete Phytophthora infestans, has historically been an important disease of potatoes and tomatoes worldwide. Prior to 1992, late blight epidemics were infrequent in most parts of the United States and Canada (10). However, in 1992 and 1993 severe late blight epidemics were reported on both potato and tomato throughout the United States and Canada, and late blight has been reported annually since that time. The disease is a constraint to potato production expansion in many developing countries (20). Late blight is responsible for the large amount of chemical fungicides applied annually to potatoes, and the development of fungicide resistance in the pathogen has exacerbated control strategies $(2,10,20)$.

In recent years late blight has become a significant problem in North Carolina (9).

Corresponding author: J. B. Ristaino

E-mail: jean_ristaino@ncsu.edu

This research was funded in part by grant number 95-37313-1941 from the National Research Initiatives Competitive Grants Program, United States Department of Agriculture.

Accepted for publication 27 May 1997.

Publication no. D-1997-0714-03R

(C) 1997 The American Phytopathological Society
Tomato production in North Carolina is primarily in the western, mountainous counties where cool, wet weather conditions are usually ideal for disease development (9). Prior to 1991, the incidence of late blight in North Carolina tomato production areas was sporadic, with epidemics occurring once every three to five years; however, in the past few years epidemics have occurred annually (9). Potato production areas of North Carolina are predominately the eastern coastal counties, where weather conditions are generally less favorable for disease development (8); however, when weather conditions are favorable an uncontrolled epidemic can result in $100 \%$ losses in some fields as occurred in 1995 (M. Cubeta, personal communication).

A rapid and accurate method for specific detection of $P$. infestans in plant material could simplify diagnosis of the disease. Infected potato tubers are likely sources of primary inoculum for potato late blight epidemics in fields in North Carolina and elsewhere $(11,14,25)$. Detection of the pathogen inoculum sources prior to planting could prevent introduction of infected material into fields, and could be an effective management practice. Multiple species of Phytophthora infect both potato and tomato, making disease diagnosis complex. Traditional isolation and identification of Phytophthora can be time consuming, thus limiting management options. A rapid diagnostic assay will aid in pathogen identification and lead to more effective management practices. At the recent North American Potato Late Blight Workshop in Tucson, Arizona (January 8 through 11, 1997) the development of a rapid diagnostic assay for late blight detection was listed as a top research priority.

Polymerase chain reaction (PCR) offers several advantages compared to more traditional methods of plant disease diagnosis: organisms need not be cultured prior to detection by PCR, the technique possesses sensitivity, and it is rapid and versatile $(15,18)$. Depending on the primers used, PCR facilitates the detection of a single pathogen or a group of related pathogens.

The objective of this research was to develop a PCR primer for specific amplification of $P$. infestans, and to develop a rapid assay for detection of the pathogen in infected plant material. The application of this technique will be useful for identification of $P$. infestans in infected potato and tomato seed sources, detection of $P$. infestans in infected plants that lack visible morphological structures or symptoms, and tracking epidemics of the past through examination of herbarium specimens (24).

\section{MATERIALS AND METHODS}

Source of isolates. $P$. infestans isolates were collected from diseased potato and tomato plants in North Carolina, Tennessee, and South Carolina from 1993 to 1996 $(8,9)$. These isolates are maintained in a collection at North Carolina State University, Department of Plant Pathology. In addition, $P$. infestans cultures were donated by various individuals. A list of $P$. infestans isolates and their sources is shown in Table 1. Isolates of Phytophthora spp., Pythium, and various other fungi and bacteria known to infect potato tubers were donated by numerous individuals. These isolates are listed in Table 2.

DNA extraction. Mycelia of each Phytophthora and Pythium isolate were obtained by growth in pea broth $(120 \mathrm{~g}$ frozen peas per liter sterile distilled water) at 18 to $25^{\circ} \mathrm{C}$ (temperature isolate dependent) for at least 1 week. Mycelia of other fungi were grown in potato dextrose broth (Difco Laboratories, Detroit) and bacteria were grown in nutrient broth (Difco Laboratories). Mycelia were harvested by filtration and frozen at $-20^{\circ} \mathrm{C}$. DNA was extracted from mycelia according to a modification of the cetyltrimethylammonium bromide 
procedure (CTAB; 7). Frozen mycelia were placed in sterile $1.5 \mathrm{ml}$ microcentrifuge tubes, $150 \mu \mathrm{l}$ extraction buffer $(0.35$ M sorbitol, 0.1 M Tris, 0.005 M EDTA, $\mathrm{pH} 7.5,0.02 \mathrm{M}$ sodium bisulfite) was added, and tubes were vortexed. Nuclei lysis buffer $(150 \mu \mathrm{l})$ containing $0.2 \mathrm{M}$ Tris, $0.05 \mathrm{M}$ EDTA, pH 7.5, 2.0 M NaCl, and 2\% CTAB (hexadecyltrimethylammonium bromide) was added, followed by $60 \mu \mathrm{l}$ of $5 \%$ sarkosyl (5 g N-lauryl sarcosine per $100 \mathrm{ml} \mathrm{H}_{2} \mathrm{O}$ ), and tubes were vortexed, then incubated at $65^{\circ} \mathrm{C}$ for 15 to $30 \mathrm{~min}$. One volume of chloroform:isoamyl alcohol (24:1) was added to each tube and centrifuged for $15 \mathrm{~min}$ at $13,000 \times \mathrm{g}$ at room temperature. The aqueous phase was removed to a new tube and the chloroform extraction was repeated. DNA was precipitated overnight at $-20^{\circ} \mathrm{C}$ in 0.1 volumes of $3 \mathrm{M}$ sodium acetate, $\mathrm{pH} 8.0$, and two volumes of cold $100 \%$ ethanol. The supernatant was discarded, the pellets were washed with $70 \%$ ethanol, then dried under vacuum centrifugation. DNA was resuspended in TE $(10 \mathrm{mM}$ Tris- $\mathrm{HCl}, 0.1 \mathrm{mM}$ EDTA, pH 8.0).

Polymerase chain reaction. PCR was conducted in $50 \mu \mathrm{l}$ reaction volumes. Each reaction consisted of approximately $50 \mathrm{ng}$ of template DNA, $5 \mu \mathrm{l} 10 \times$ PCR buffer (Boehringer Mannheim Biochemicals, Indianapolis, IN), $36.6 \mu \mathrm{l}$ sterile distilled H2O, $2 \mu \mathrm{l}$ 1.25-2.0 mM dNTPs (Pharmacia LKB Biotechnology, Inc., Piscataway, NJ), $2 \mu \mathrm{l} 10 \mathrm{mM} \mathrm{MgCl}_{2}$ (Sigma Chemical Co., St. Louis), $2 \mu$ l each of $10 \mu \mathrm{m}$ internal transcribed spacer (ITS) 4 and ITS5 primers (29), and $0.4 \mu \mathrm{l}$ Taq polymerase (5 $\mathrm{U} / \mu \mathrm{l}$, Boehringer Mannheim Biochemicals). All reactions were overlaid with sterile mineral oil prior to thermal cycling. Thermal cycling parameters were initial denaturation at $96^{\circ} \mathrm{C}$ for $2 \mathrm{~min}$, followed by 35 cycles consisting of denaturation at $96^{\circ} \mathrm{C}$ for $1 \mathrm{~min}$, annealing at $55^{\circ} \mathrm{C}$ for $1 \mathrm{~min}$, and extension at $72^{\circ} \mathrm{C}$ for $2 \mathrm{~min}$. A final extension at $72^{\circ} \mathrm{C}$ for $10 \mathrm{~min}$ followed. Negative controls (no template DNA) were used in every experiment to test for the presence of contamination in reagents.

Amplified products from $P$. infestans isolates $115,90,91$, and 116 , representing the US1, US6, US7, and US8 genotypes, respectively, were purified using GeneClean (Bio 101, Vista, CA) according to the manufacturer's recommendations. These PCR products were sent to Iowa State University (Ames) for automated DNA sequencing on an ABI Prism System automated sequencer (Model 377, version 2.1.1, Perkin-Elmer Corp., Norwalk, CT). Sequences were aligned with published sequences from five other Phytophthora species (17) using CLUSTAL V (16). A region specific to $P$. infestans was identified and used to design a PCR primer (PINF). The PINF primer was synthesized by Gibco BRL (Gaithersburg, MD). PCR conditions used with the primer were identical to those described above, except that primers PINF and ITS5 were used.

Screening of PINF primer. Over 140 isolates representing 14 species of Phy- tophthora and 13 genera of other fungi and bacteria (Tables 1 and 2) were used to screen the PINF primer. PCR conditions were as described above using primers PINF and ITS5. PCR reactions with primers ITS4 and ITS5 (29) were performed for all fungal isolates as a positive control to ensure the template DNA was amplifiable. Similar control reactions were performed with the bacterial isolates using bacterial repetitive extragenic palindromic (REP) PCR primers (27). Amplified products were electrophoresed on $1.6 \%$ agarose gels containing $0.5 \mu \mathrm{g} / \mathrm{ml}$ ethidium bromide with $1 \times$ TBE running buffer. A 100-basepair (bp) DNA ladder (Gibco BRL) was included on each gel as a molecular size standard.

PCR amplification from diseased plant tissue. Lesions obtained from diseased potato plants collected in Pasquotank and Yadkin counties in North Carolina in 1996, and from diseased tomato leaves and fruits collected in Fletcher and Waynesville, North Carolina in 1996, were excised and subjected to a $\mathrm{NaOH}$ lysis as preparation for PCR according to the method of Wang et al. (28). In addition, potato tuber slices were inoculated with $P$. infestans isolate 90 in the lab and, after approximately 1 week, small tuber pieces were lysed with $\mathrm{NaOH}$ for subsequent PCR. Healthy leaf pieces from tomato and healthy potato tuber pieces were included in the $\mathrm{NaOH}$ extractions and subsequent PCR reactions as negative controls. The $\mathrm{NaOH}$ lysis procedure consisted of grind-

Table 1. Isolates of Phytophthora infestans used to screen the polymerase chain reaction primer (PINF)

\begin{tabular}{|c|c|c|c|c|c|c|}
\hline Isolate & Species & Mating Type & Genotype & Host & Source & Product with PINF \\
\hline 90 & P. infestans & A1 & US6 & Potato & W. Fry & + \\
\hline 91 & $P$. infestans & $\mathrm{A} 2$ & US7 & Potato & W. Fry & + \\
\hline $93-2$ & P. infestans & A2 & US7 & Tomato & P. Shoemaker & + \\
\hline $93-1$ & P. infestans & A2 & US7 & Tomato & P. Shoemaker & + \\
\hline $93-4$ & P. infestans & A2 & US8 & Tomato & P. Shoemaker & + \\
\hline $93-5$ & P. infestans & A2 & US7 & Tomato & P. Shoemaker & + \\
\hline $94-8-1$ & P. infestans & $\mathrm{A} 2$ & US8 & Potato & P. Shoemaker & + \\
\hline $94-7$ & P. infestans & A2 & US7 & Potato & P. Shoemaker & + \\
\hline $94-19$ & $P$. infestans & $\mathrm{A} 2$ & US8 & Tomato & P. Shoemaker & + \\
\hline $94-37$ & P. infestans & A2 & US7 & Potato & P. Shoemaker & + \\
\hline 115 & $P$. infestans & $\mathrm{A} 1$ & US1 & Potato & B. Christ & + \\
\hline 116 & P. infestans & A2 & US8 & Potato & B. Christ & + \\
\hline $94-1$ & $P$. infestans & A1 & US1 & Potato & P. Shoemaker & + \\
\hline 188.1.1 & P. infestans & $\mathrm{A} 1$ & US1 & Potato & Z. Punja & + \\
\hline 336.1 .4 & P. infestans & A1 & US1 & Potato & Z. Punja & + \\
\hline 342.1 .1 & $P$. infestans & $\mathrm{A} 1$ & & Potato & Z. Punja & + \\
\hline 268.1.5 & P. infestans & A1 & & Potato & Z. Punja & + \\
\hline 2.1 .3 & $P$. infestans & $\mathrm{A} 2$ & & Potato & Z. Punja & + \\
\hline ME920094 & P. infestans & A2 & US8 & Potato & W. Fry & + \\
\hline ME880153 & $P$. infestans & A1 & & Potato & W. Fry & + \\
\hline CA920008 & P. infestans & $\mathrm{A} 2$ & & Potato & W. Fry & + \\
\hline US920141 & P. infestans & A1 & US1 & Potato & W. Fry & + \\
\hline $96-3-1$ & P. infestans & $\mathrm{A} 2$ & US8 & Potato & M. Cubeta & + \\
\hline $96-3-2$ & P. infestans & A2 & US8 & Potato & M. Cubeta & + \\
\hline $96-5$ & $P$. infestans & $\mathrm{A} 2$ & US8 & Potato & M. Cubeta & + \\
\hline $18 / 94$ & P. infestans & A1 & & Potato & L. Cooke & + \\
\hline $32 / 94$ & P. infestans & A1 & & Potato & L. Cooke & + \\
\hline $51 / 94$ & $P$. infestans & A1 & & Potato & L. Cooke & + \\
\hline $57 / 94$ & P. infestans & $\mathrm{A} 1$ & & Potato & L. Cooke & + \\
\hline $11 / 95$ & $P$. infestans & $\mathrm{A} 1$ & & Potato & L. Cooke & + \\
\hline $24 / 95$ & P. infestans & A1 & & Potato & L. Cooke & + \\
\hline $31 / 95$ & $P$. infestans & A1 & & Potato & L. Cooke & + \\
\hline
\end{tabular}


ing a few milligrams of plant tissue in 0.5 $\mathrm{N} \mathrm{NaOH}(10 \mu \mathrm{l} / \mathrm{mg})$, then immediately transferring $5 \mu \mathrm{l}$ of this extract to a sterile $1.5 \mathrm{ml}$ tube containing $495 \mu \mathrm{l} 100 \mathrm{mM}$ Tris, $\mathrm{pH}$ 8.0. One microliter of this extract was used as the DNA template for PCR. The conditions for PCR were identical to those described above for amplification with the PINF primer. PCR reactions were repeated at least two times. $P$. infestans was isolated into pure culture from the diseased tissue by isolating sporangia and transferring them to Rye B agar (extract from $60 \mathrm{~g}$ rye grains, $20 \mathrm{~g}$ sucrose, $15 \mathrm{~g}$ agar, $0.05 \mathrm{~g} \beta$ sitosterol per liter).

\section{RESULTS}

Sequence analysis. Sequences from the ITS2 of $P$. infestans isolates 90, 91, 115, and 116 were aligned with previously published sequences from a similar region of $P$. capsici, $P$. cinnamomi, $P$. citrophthora, P. megakarya, and P. palmivora (17). A 20base sequence (CTCGCTACAATAGGAGGGTC) was identified from which a potential $P$. infestans-specific primer (PINF) was synthesized. Entire ITS2 ribosomal DNA (rDNA) sequences from $P$. infestans isolates 90, 91, 115, and 116 have been submitted to GenBank (Accession numbers AF004277, AF004278, AF004279, and AF004280, respectively).
Amplification with PINF. Over 140 isolates representing 14 species of Phytophthora and 13 other genera of fungi and bacteria were examined in PCR reactions with primers PINF and ITS5. Only isolates representing $P$. infestans, $P$. mirabilis, and $P$. cactorum yielded a product approximately $600 \mathrm{bp}$ in size when amplified with primers PINF and ITS5 (Fig. 1, lanes 2, 3, and 13). Isolates representing all other Phytophthora species and other genera tested yielded no amplification product with the PINF/ITS5 primer combination (Table 2, Fig. 1). Control reactions with the ITS4/ITS5 primer combination and REP PCR primers yielded amplified products

Table 2. Isolates of fungi and bacteria used to screen the polymerase chain reaction primer (PINF) for amplification specific to Phytophthora infestans

\begin{tabular}{|c|c|c|c|c|}
\hline Isolate & Species & Host & Source & Product with PINF \\
\hline $127 / 77$ & Phytophthora cactorum & Unknown & L. Cooke & + \\
\hline $234 / 81$ & P. cactorum & Unknown & L. Cooke & + \\
\hline 1298 & P. cactorum & Unknown & G. Weidemann & + \\
\hline SC1A & P. capsici & Pepper & J. Ristaino & - \\
\hline 18 & P. capsici & Pepper & J. Ristaino & - \\
\hline 28 & P. capsici & Pepper & J. Ristaino & - \\
\hline B1HB14 & P. capsici & Pepper & J. Ristaino & - \\
\hline B2HH4 & P. capsici & Pepper & J. Ristaino & - \\
\hline 2301 & P. cinnamomi & Rhododendron & M. Benson & - \\
\hline 2302 & P. cinnamomi & Fraser Fir & M. Benson & - \\
\hline 2322 & P. cinnamomi & Camellia & M. Benson & - \\
\hline 2325 & P. cinnamomi & Shore Juniper & M. Benson & - \\
\hline 2337 & P. cinnamomi & Azalea & M. Benson & - \\
\hline 2349 & P. cinnamomi & Leucothe & M. Benson & - \\
\hline $34-2-8$ & P. cinnamomi & Walnut & J. Mircetich & - \\
\hline $34-1-1$ & P. citricola & Walnut & J. Mircetich & - \\
\hline M213 & P. citricola & Avocado & J. Menge & - \\
\hline M215 & P. citricola & Avocado & J. Menge & - \\
\hline M220 & P. citricola & Avocado & J. Menge & - \\
\hline M265 & P. citricola & Avocado & J. Menge & - \\
\hline M266 & P. citricola & Avocado & J. Menge & - \\
\hline $34-4-7$ & P. citrophthora & Citrus & J. Mircetich & - \\
\hline M86 & P. citrophthora & Citrus & J. Menge & - \\
\hline M139 & P. citrophthora & Citrus & J. Menge & - \\
\hline M140 & P. citrophthora & Citrus & J. Menge & - \\
\hline M189 & P. citrophthora & Citrus & J. Menge & - \\
\hline M259 & P. citrophthora & Citrus & J. Menge & - \\
\hline $34-1-7$ & P. cryptogea & Safflower & J. Duniway & - \\
\hline PCR-1 & P. cryptogea & Safflower & J. Duniway & - \\
\hline $34-3-2$ & P. drechsleri & Unknown & J. Mircetich & - \\
\hline 4 & P. erythroseptica & Potato & J. Duniway & - \\
\hline 10 & P. erythroseptica & Potato & J. Duniway & - \\
\hline 11 & P. erythroseptica & Potato & J. Duniway & - \\
\hline A-8 & $P$. fragariae & Strawberry & B. Milholland & - \\
\hline $\mathrm{R}-4$ & P. fragariae & Strawberry & B. Milholland & - \\
\hline NC-1 & P. fragariae & Strawberry & B. Milholland & - \\
\hline $\mathrm{R}-1$ & P. fragariae & Strawberry & B. Milholland & - \\
\hline R-6 & P. fragariae & Strawberry & B. Milholland & - \\
\hline NY318 & P. megasperma & Raspberry & W. Wilcox & - \\
\hline NY321 & P. megasperma & Raspberry & W. Wilcox & - \\
\hline NY222 & P. megasperma & Apricot & W. Wilcox & - \\
\hline NY344 & P. megasperma & Cherry & W. Wilcox & - \\
\hline NY346 & P. megasperma & Cherry & W. Wilcox & - \\
\hline NY412 & P. megasperma & Peach & W. Wilcox & - \\
\hline $33-2-9$ & P. megasperma & Apple & J. Mircetich & - \\
\hline OS0016 & P. mirabilis & Mirabilis jalapa & W. Fry & + \\
\hline Rmt6 & P. nicotianae & Tobacco & D. Shew & - \\
\hline 332 & P. nicotianae & Tobacco & D. Shew & - \\
\hline 340 & P. nicotianae & Tobacco & D. Shew & - \\
\hline 335 & P. nicotianae & Tobacco & D. Shew & - \\
\hline 435 & P. nicotianae & Tobacco & D. Shew & - \\
\hline $1-3 \mathrm{~A}$ & P. nicotianae & Tomato & J. Ristaino & - \\
\hline $6-1 \mathrm{~A}$ & P. nicotianae & Tomato & J. Ristaino & - \\
\hline
\end{tabular}


with all isolates tested (results not shown).

Restriction digests were performed on the amplified products from $P$. infestans, $P$. mirabilis, and $P$. cactorum in an attempt to differentiate isolates of these species (Fig. 2). The 600 bp product amplified from $P$. cactorum using the PINF primer was digested with HaeIII (lane 8); however, the amplified product from $P$. infestans and $P$. mirabilis were not digested with HaeIII (lanes 6 and 7). Restriction digests with additional endonucleases have not differentiated $P$. infestans from $P$. mirabilis.

PCR amplification from diseased plant tissue. A single PCR product ap- proximately $600 \mathrm{bp}$ in size was detected in late blight-infected potato and tomato samples collected from North Carolina in 1996 (Fig. 3). Confirmation of the presence of $P$. infestans in the diseased plants was made by isolating the fungus from the tissue into pure culture. No product was detected in healthy tissue (Fig. 3, lanes 7 and 12). The $\mathrm{NaOH}$ lysis technique was rapid and eliminated the necessity to perform laborious DNA extractions prior to PCR amplification.

\section{DISCUSSION}

The objective of this work was to develop a PCR primer for specific amplifica- tion of $P$. infestans in diseased potato and tomato tissue. Amplification with the PINF primer resulted in an approximately $600 \mathrm{bp}$ product with isolates of $P$. infestans, $P$. mirabilis, and $P$. cactorum. Of these 3 species, only $P$. infestans has been reported to infect potato, and only $P$. infestans and $P$. cactorum have been reported to infect tomato (5). Restriction digests of the resulting PCR products with HaeIII differentiated $P$. infestans from $P$. cactorum. Isolates of $P$. mirabilis were not differentiated from those of $P$. infestans via restriction digestion. $P$. mirabilis has been reported as specific to Mirabilis jalapa in Mexico and is not a pathogen of potato

Table 2. (continued from previous page)

\begin{tabular}{|c|c|c|c|c|}
\hline Isolate & Species & Host & Source & Product with PINF \\
\hline $5-3 \mathrm{~A}$ & P. nicotianae & Tomato & J. Ristaino & - \\
\hline $2 \mathrm{HB}$ & P. nicotianae & Tomato & J. Ristaino & - \\
\hline $6-\mathrm{H}$ & P. nicotianae & Tomato & J. Ristaino & - \\
\hline 2107 & P. nicotianae & Boxwood & M. Benson & - \\
\hline 2127 & P. nicotianae & Vinca & M. Benson & - \\
\hline 2109 & P. nicotianae & Rhododendron & M. Benson & - \\
\hline 2116 & P. nicotianae & Rhododendron & M. Benson & - \\
\hline 2121 & P. nicotianae & Azalea & M. Benson & - \\
\hline $\mathrm{R} 1$ & P. sojae & Soybean & X. B. Yang & - \\
\hline R3 & P. sojae & Soybean & X. B. Yang & - \\
\hline $\mathrm{R} 4$ & P. sojae & Soybean & X. B. Yang & - \\
\hline R8 & P. sojae & Soybean & X. B. Yang & - \\
\hline $\mathrm{R} 13$ & P. sojae & Soybean & X. B. Yang & - \\
\hline $\mathrm{R} 25$ & P. sojae & Soybean & X. B. Yang & - \\
\hline L22-3 & Pythium aphanidermatum & Cucumber & G. Abad & - \\
\hline L74-2 & Pythium irregulare & Turf grass & G. Abad & - \\
\hline $1 \mathrm{~A}$ & Alternaria solani & Potato & P. Shoemaker & - \\
\hline 2 & Alternaria solani & Potato & P. Shoemaker & - \\
\hline 3 & Alternaria solani & Potato & P. Shoemaker & - \\
\hline 4 & Alternaria solani & Potato & P. Shoemaker & - \\
\hline CH3-2 & Botrytis cinerea & Strawberry & F. Louws & - \\
\hline A1-3 & Botrytis cinerea & Strawberry & F. Louws & - \\
\hline LRSJ27-LY & Fusarium sambucinum & Potato & R. Loria & - \\
\hline Caco-2 & Fusarium solani & Potato & R. Loria & - \\
\hline F-1 & Fusarium spp. & Sweet Potato & J. Ristaino & - \\
\hline F-3 & Fusarium spp. & Sweet Potato & J. Ristaino & - \\
\hline F-5 & Fusarium spp. & Sweet Potato & J. Ristaino & - \\
\hline $12 \mathrm{SS} 2$ & Helminthosporium solani & Potato & R. Loria & - \\
\hline 19SS2T1 & Helminthosporium solani & Potato & R. Loria & - \\
\hline R-109 & Rhizoctonia solani & Potato & J. Ristaino & - \\
\hline AG3NC1 & Rhizoctonia solani & Potato & M. Cubeta & - \\
\hline AG3SC1 & Rhizoctonia solani & Potato & M. Cubeta & - \\
\hline SS-DD-1 & Sclerotinia sclerotiorum & Lettuce & J. Ristaino & - \\
\hline $\mathrm{T} 1$ & Sclerotinia sclerotiorum & Cabbage & P. Weingartner & - \\
\hline SR-DD-5 & Sclerotium rolfsii & Tomato & J. Ristaino & - \\
\hline SR-DD-8 & Sclerotium rolfsii & Tomato & J. Ristaino & - \\
\hline SR-DD-9 & Sclerotium rolfsii & Tomato & J. Ristaino & - \\
\hline SR-DD-10 & Sclerotium rolfsii & Tomato & J. Ristaino & - \\
\hline 462 & Verticillium albo atrum & Soil & R. Rowe & - \\
\hline Kricken & Verticillium dahliae & Potato & J. Ristaino & - \\
\hline 21 & Verticillium dahliae & Potato & R. Rowe & - \\
\hline 30 & Verticillium dahliae & Potato & R. Rowe & - \\
\hline CMS-1 & Clavibacter michiganensis subsp. sepedonicus & Potato & D. Mills & - \\
\hline CMS-2 & Clavibacter michiganensis subsp. sepedonicus & Potato & D. Mills & - \\
\hline CMS-7 & Clavibacter michiganensis subsp. sepedonicus & Potato & D. Mills & - \\
\hline CMS-8 & Clavibacter michiganensis subsp. sepedonicus & Potato & D. Mills & - \\
\hline 6.1 .3 & Erwinia carotovora subsp. carotovora & Pepper & D. TeBeest & - \\
\hline 177 & Erwinia carotovora subsp. carotovora & Potato & A. Kelman & - \\
\hline 178 & Erwinia carotovora subsp. carotovora & Potato & A. Kelman & - \\
\hline K60 & Pseudomonas solanacearum & Tomato & A. Kelman & - \\
\hline K86 & Pseudomonas solanacearum & Tomato & A. Kelman & - \\
\hline K148 & Pseudomonas solanacearum & Banana & A. Kelman & - \\
\hline SS-1 & Streptomyces scabies & Potato & C. Clark & - \\
\hline S88-01-22 & Streptomyces scabies & Potato & R. Loria & - \\
\hline S84-01-34 & Streptomyces scabies & Potato & R. Loria & - \\
\hline
\end{tabular}


(12). Results of other molecular studies have suggested that $P$. infestans and $P$. mirabilis are closely related $(4,19)$. Möller et al. (19) suggested that $P$. mirabilis should be considered a forma specialis of $P$. infestans. The results of the present study support the findings of other studies, in that $P$. infestans and $P$. mirabilis appear to have similar rDNA ITS sequences. We have not sequenced $P$. mirabilis ITS DNA to examine sequence homology between the two species.

Farr et al. (5) listed 5 species of Phytophthora that infect potato and 8 species

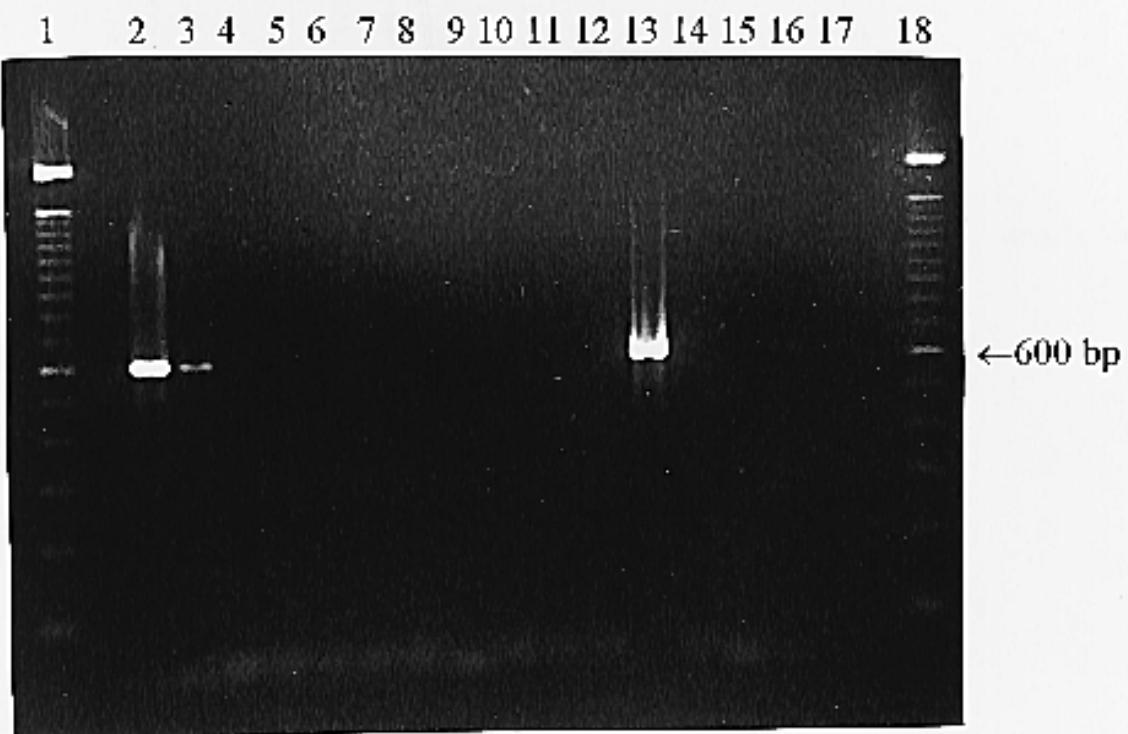

Fig. 1. Agarose gel containing amplified products from polymerase chain reaction amplification with primers PINF and internal transcribed spacer 5 of representative isolates of 14 species of Phytophthora and 2 species of Pythium. Isolates include: Phytophthora infestans 90 (lane 2), P. cactorum 1298 (lane 3), P. capsici SC1A (lane 4), P. cinnamomi 2301 (lane 5), P. citricola M213 (lane 6), $P$. citrophthora M86 (lane 7), P. cryptogea PCR-1 (lane 8), P. drechsleri 34-3-2 (lane 9), P. erythroseptica 10 (lane 10), P. fragariae R-4 (lane 11), P. megasperma NY321 (lane 12), P. mirabilis OS0016 (lane 13), P. nicotianae 332 (lane 14), P. sojae R1 (lane 15), Pythium aphanidermatum L22-3 (lane 16), Pythium irregulare L74-2 (lane 17). Lanes 1 and 18 contain a 100-bp DNA ladder.

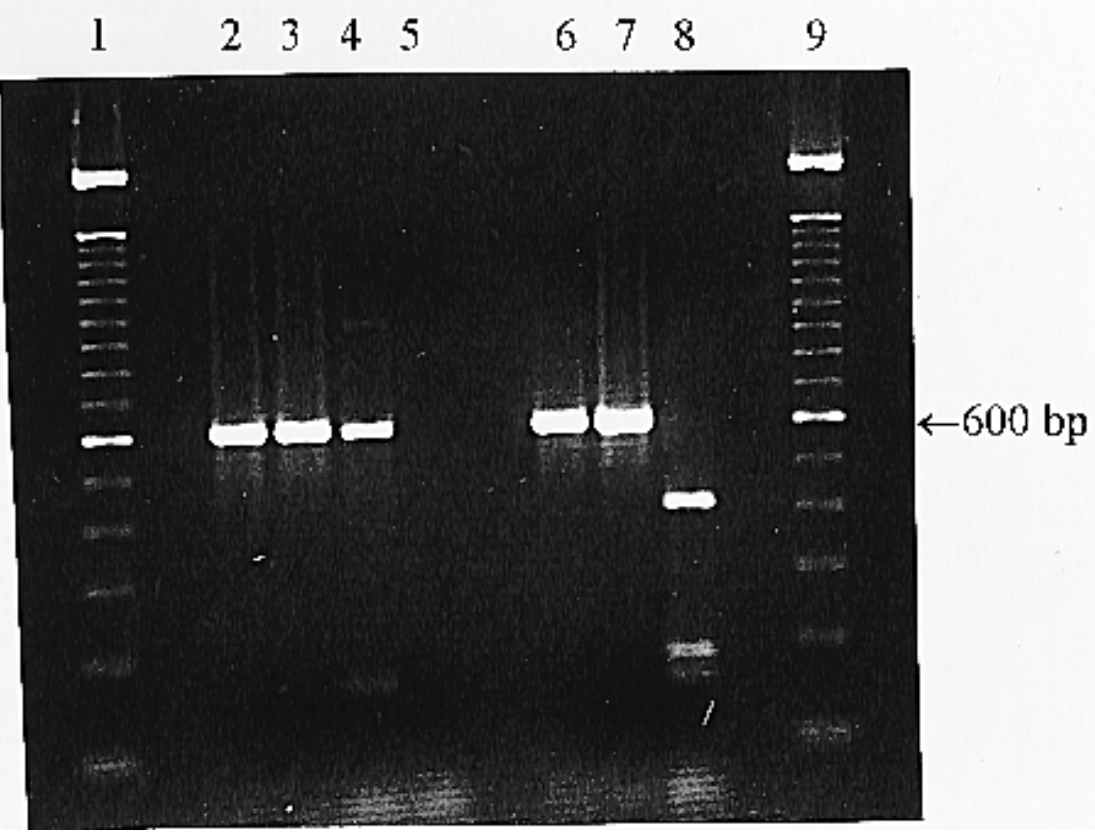

Fig. 2. PINF amplification of Phytophthora infestans, P. mirabilis, and P. cactorum, and HaeIII restriction digestion of the 600-bp product differentiating $P$. infestans from P. cactorum. Lanes 2, 3, and 4: PINF amplification products of P. infestans 90, P. mirabilis OS0016, and P. cactorum 1298, respectively. Lane 5: no template DNA control. Lanes 6, 7, and 8: HaeIII digests of PINF amplification products of $P$. infestans 90, P. mirabilis OS0016, and $P$. cactorum 1298, respectively. Lanes 1 and 9 contain a $100-$ bp DNA ladder. that infect tomato. Isolates representing the 5 species known to infect potato $(P$. infestans, $P$. cryptogea, $P$. drechsleri, $P$. erythroseptica, and $P$. nicotianae var. parasitica) were examined in this study, and only $P$. infestans isolates yielded amplification products with the PINF primer. These same isolates can be differentiated to species using restriction digestion of rDNA amplified with the universal primers ITS4 and ITS5 (23). Of the 8 species known to infect tomato, 7 species $(P$. infestans, $P$. cactorum, $P$. capsici, $P$. cinnamomi, $P$. cryptogea, $P$. drechsleri, and $P$. nicotianae [formerly $P$. parasitica]) were examined in this study. Only $P$. infestans and $P$. cactorum yielded amplification products with the PINF primer. As discussed previously, restriction digests of the amplification products with HaeIII differentiated $P$. infestans and P. cactorum. Isolates representing 7 of the species known to infect tomato can be differentiated to species using restriction digestion of rDNA amplified with the universal primers ITS4 and ITS5 (23).

Molecular tools including isozyme analysis, restriction fragment length polymorphisms in nuclear and mitochondrial DNA, random amplified polymorphic DNA PCR, serological assays, DNA probes, and PCR of ITS regions and nuclear small and large subunit rRNA have been developed to evaluate intraspecific and interspecific variation in Phytophthora species $(3,6,13,17,18,21,22)$. Most of these techniques involve isolating the pathogen into pure culture and complex extraction procedures to isolate DNA or examine proteins. Recently, Tooley et al. (26) reported the development of PCR primers to detect 3 species of Phytophthora infecting potato. Their work has focused only on isolates infecting potato, and the specificity of their primers has not been tested on the range of fungi and bacteria examined in our present study. In addition, all the Phytophthora species that infect potato were not tested in the previously reported work (26). Late blight of tomato is a serious problem in California, North Carolina, Florida and other tomato production areas $(1,8,9)$. The technique described in this paper is applicable to isolates of $P$. infestans infecting both tomato and potato, is relatively rapid, and eliminates the need to isolate the pathogen into pure culture and extract DNA prior to PCR amplification.

$P$. infestans is difficult to identify when sporangia or other characteristic morphological structures are absent and may be confused with other Phytophthora species. Also, $P$. infestans is difficult to isolate into pure culture, and traditional culture work is time-consuming. The techniques described herein eliminate the need for pure culture isolation. We have adopted a quick lysis assay for use with infected plant material that eliminates the need for complex ex- 


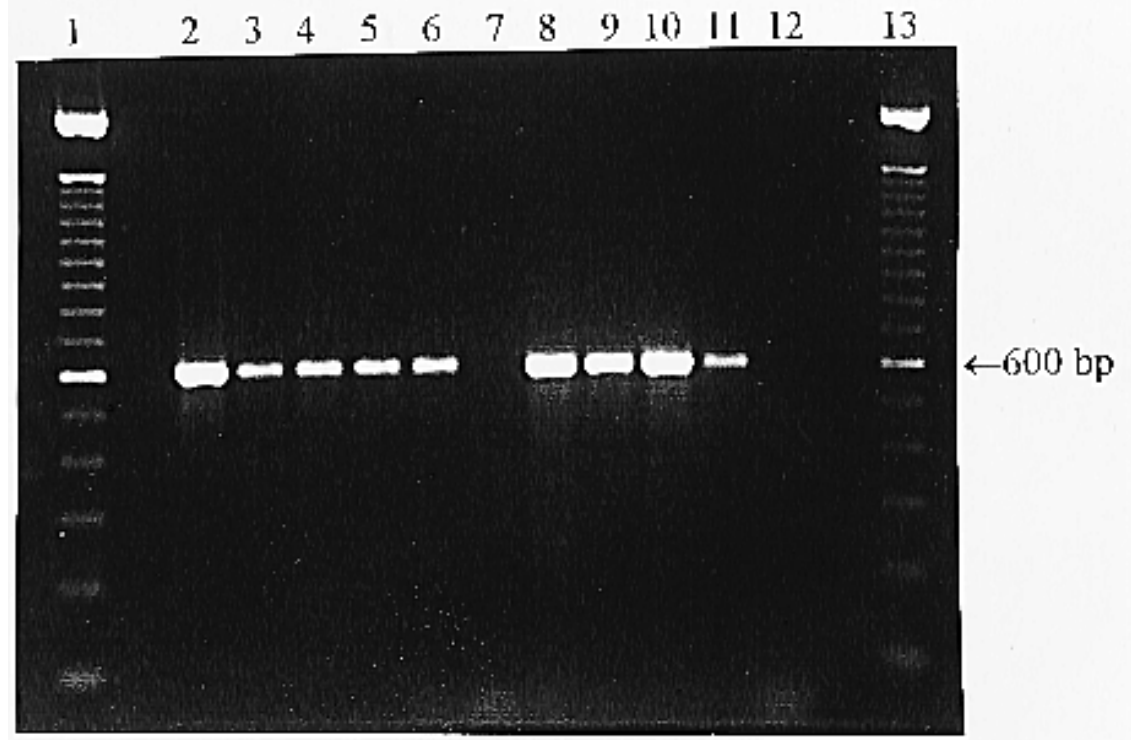

Fig. 3. Amplification of 600-bp product from late blight-infected potato and tomato with the PINF primer. Phytophthora infestans 90 pure culture (lane 2), potato leaf lesion from Pasquotank County (lanes 3 and 4), potato leaf lesion from Yadkin County (lane 5), potato tuber inoculated with isolate 90 (lane 6), healthy potato tuber (lane 7), tomato leaf lesion from Fletcher, NC (lane 8), tomato fruit lesion from Fletcher, NC (lane 9), tomato leaf lesion from Waynesville, NC (lane 10), tomato fruit lesion from Waynesville, NC (lane 11), healthy tomato leaf (lane 12). Lanes 1 and 13 contain a 100bp DNA ladder.

tractions of pathogen DNA prior to PCR (28). These techniques, coupled with traditional disease diagnostics, should provide rapid, accurate diagnosis of late blightinfected plants, leading to more effective disease management practices and minimal losses from disease.

The PINF primer will provide an important diagnostic tool for detection of $P$. infestans in seed potatoes and tomato transplants. At the recent North American Potato Late Blight Workshop held in January of 1997, research workers stated priorities for research. The development of quick, reliable, and inexpensive late blight diagnostic techniques for laboratory, storage, and field use for large numbers of seed potatoes was a number one priority. In addition, the development of quick identification techniques for detection of the pathogen in tomato transplants and in the field was a second priority. Investigation of inoculum sources and the epidemiology of tuber blight in storage and in the field were also ranked high in the list of research priorities. National protocols for inspecting and sampling potato seed crops for late blight prior to shipping are under development by seed growers. We have sampled seed potatoes entering North Carolina from various sources, and are now using the primer to test for latent infections. We are also optimizing sampling size and minimum detection levels of the pathogen with the primer. In May of 1997 we sampled from a new outbreak of late blight in a field in Washington County, North Carolina and found seed piece, stolen, and tuber infection in the field (J. Ristaino, unpublished). Further investigations of this and other potato late blight epidemics will be conducted using the PINF primer.

We are currently negotiating a licensing agreement for the PINF primer, and a commercial diagnostic assay incorporating the primer should be available in the near future.

\section{ACKNOWLEDGMENTS}

We thank Dawn Fraser, Paul Shoemaker, and tomato and potato stimulated parts of this research; and David Francis (Ohio State University) and Dina St. Clair (University of California, Davis) for their guidance on the initial PCR protocols adopted in this work.

\section{LITERATURE CITED}

1. Coffey, M. D., Mickler, C. J., Duan, C.-L., Förster, H., and Paulus, A. O. 1996. Emergence of late blight as a major threat to tomato and potato production in California. (Abstr.) Phytopathology 86:S5

2. Deahl, K. L., Inglis, D. A., and DeMuth, S. P. 1993. Testing for resistance to metalaxyl in Phytophthora infestans isolates from northwestern Washington. Am. Potato J. 70:779795.

3. Ersek, T., Schoelz, J. E., and English, J. T. 1994. PCR amplification of species-specific DNA sequences can distinguish among Phytophthora species. Appl. Environ. Microbiol. 60:2616-2621.

4. Falkenstein, K. F., Tooley, P. W., Goodwin, S. B., and Fry, W. E. 1991. Differentiation of group IV Phytophthora species by PCR amplification of nuclear ribosomal DNA internal transcribed spacer region. (Abstr.) Phytopathology 81:1157.

5. Farr, D. F., Bills, G. F., Chamuris, G. P., and Rossman, A. Y. 1989. Fungi on Plants and Plant Products in the United States. American Phytopathological Society, St. Paul, MN.

6. Förster, H., Oudemans, P., and Coffey, M. D. 1990. Mitochondrial and nuclear DNA diversity within six species of Phytophthora. Exp. Gloria Abad, whose work with $P$. infestans on
Mycol. 14:18-31.

7. Francis, D. M., and St. Clair, D. A. 1993 Outcrossing in the homothallic oomycete Pythium ultimum, detected with molecular markers. Curr. Genet. 24:100-106.

8. Fraser, D. E. 1996. Phenotypic and genotypic diversity of isolates of Phytophthora infestans from North Carolina and evaluation of tomato breeding lines for resistance to late blight (Master's Thesis). North Carolina State University.

9. Fraser, D. E., Shoemaker, P. B., and Ristaino, J. B. 1995. Characterization of Phytophthora infestans isolates from tomato and potato in North Carolina, USA, 1993. Pages 102-106 in: Phytophthora infestans 150- European Association for Potato Research, Pathology Section Conference. L. J. Dowley, E. Bannon, L. R. Cooke, T. Keane, and E. O. Sullivan, eds. Boole Press, Ltd., Dublin, Ireland.

10. Fry, W. E., Goodwin, S. B., Dyer, A. T., Matuszak, J. M., Drenth, A., Tooley, P. W., Sujkowski, L. S., Koh, Y. J., Cohen, B. A. Spielman, L. J., Deahl, K. L., Inglis, D. A., and Sandlan, K. P. 1993. Historical recent migrations of Phytophthora infestans: chronology, pathways, and implications. Plant Dis 77:653-661.

11. Fry, W. E., Goodwin, S. B., Matuszak, J. M., Spielman, L. J., Milgroom, M. G., and Drenth, A. 1992. Population genetics and intercontinental migrations of Phytophthora infestans. Annu. Rev. Phytopathol. 30:107129.

12. Galindo, A. J., and Hohl, H. R. 1985. Phytophthora mirabilis, a new species of Phytophthora. Sydowia Ann. Mycol. 38:87-96.

13. Goodwin, P. H., Kirkpatrick, B. C., and Duniway, J. M. 1989. Cloned DNA probes for identification of $P$. parasitica. Phytopathology 79:716-721.

14. Goodwin, S. B., Cohen, B. A., Deahl, K. L., and Fry, W. E. 1994. Migration from northern Mexico as the probable cause of recent genetic changes in populations of Phytophthora infestans in the United States and Canada. Phytopathology 84:533-558.

15. Henson, J. M., and French, R. 1993. The polymerase chain reaction and plant disease diagnosis. Annu. Rev. Phytopathol. 31:81109.

16. Higgins, D. G., and Sharp, P. M. 1989. Fast and sensitive multiple sequence alignments on a microcomputer. CABIOS 5:151-153.

17. Lee, S. B., and Taylor, J. W. 1992. Phylogeny of five fungus-like Protoctistan Phytophthora species, inferred from the internal transcribed spacers of ribosomal DNA. Mol. Biol. Evol. 94:636-653.

18. Lee, S. B., White, T. J., and Taylor, J. W. 1993. Detection of Phytophthora species by oligonucleotide hybridization to amplified ribosomal DNA spacers. Phytopathology 83:177-181.

19. Möller, E. M., de Cock, A. W. A. M., and Prell, H. H. 1993. Mitochondrial and nuclear DNA restriction enzyme analysis of the closely related Phytophthora species P. in festans, P. mirabilis, and $P$. phaseoli. J. Phytopathol. 139:309-321.

20. Niederhauser, J. S. 1993. International cooperation in potato research and development. Annu. Rev. Phytopathol. 31:1-21.

21. Oudemans, P., and Coffey, M. D. 1991. A revised systematics of twelve papillate Phytophthora species based on isozyme analysis. Mycol. Res. 95:1025-1046.

22. Panabieres, F., Marais, A., Trentin, F., Bonnet, P., and Ricci, P. 1989. Repetitive DNA polymorphism analysis as a tool for identifying Phytophthora species. Phytopathology 79:1105-1109.

23. Ristaino, J. B., Parra, G., Madritch, M., 
French, R., and Fraser, D. 1995. PCR amplification of ribosomal DNA for species identification of Phytophthora. (Abstr.) Phytopathology $85: 1176$

24. Ristaino, J. B., Trout, C. L., and Madritch, M. 1996. Oospores observed in P. infestans infected herbarium specimens of potato from the early 1900's. (Abstr.) Phytopathology 86:S84.

25. Stevenson, W. R. 1993. Management of early blight and late blight. Pages 141-147 in: Potato Health Management. R. C. Rowe, ed. American
Phytopathology Society, St. Paul, MN.

26. Tooley, P. W., Bunyard, B. A., Carras, M. M., and Hatziloukas, E. 1997. Development of PCR primers from internal transcribed spacer region 2 for detection of Phytophthora species infecting potatoes. Appl. Environ. Microbiol. 63:1467-1475.

27. Vera Cruz, C. M., Ardales, E. Y., Skinner, D. Z., Talag, J., Nelson, R. J., Louws, F. J., Leung, H., Mew, T. W., and Leach, J. E. 1996. Measurement of haplotypic variation in Xanthomonas oryzae within a single field by rep-
PCR and RFLP analyses. Phytopathology 86:1352-1359.

28. Wang, H., Qi, M., and Cutler, A. J. 1993. A simple method of preparing plant samples for PCR. Nucl. Acids Res. 21:4153-4154.

29. White, T. J., Bruns, T., Lee, S. B., and Taylor, J. 1990. Amplification and direct sequencing of fungal ribosomal RNA genes for phylogenetics. Pages 315-322 in: PCR protocols: a Guide to Methods and Applications. M. A Innis, D. H. Gelfand, J. J. Sninsky, and T. J. White, eds. Academic Press, San Diego, CA. 